\title{
Economic Instruments for Environmental Sustainability in the Nigerian Oil and Gas Sector
}

\author{
Abiodun Edward Adelegan* \& Nyaluaziba Samuel Itesi \\ Department of Economics and Development Studies, Federal University Otuoke, Bayelsa State, Nigeria
}

DOI: $10.36348 /$ sjef.2019.v03i12.005

| Received: 29.10.2019 | Accepted: 05.11.2019 | Published: 30.12.2019

*Corresponding author: Abiodun Edward Adelegan

Abstract

The major purpose of economic instruments is to control pollution by harnessing the power of market incentives. Against this background, this paper examined and assessed the use of economic instruments for environmental sustainability in the Nigerian oil and gas sector. The political economy method was adopted to illuminate the issues surrounding the use of economic instruments in Nigeria. The study found that the use of economic instruments has not been effective in the Nigerian oil and gas sector. This was due mainly to inadequacies of economic instruments in use. The study thus recommended a combination of command - and - control tools and market based instruments to combat environmental problems in the oil and gas sector. Also, the government should muster sufficient will and determination to enforce the content of the Gas Flaring (Prevention of Waste Pollution) Regulation 2018.

Keywords: Economic instruments, intergenerational equity, command - and - control tools, environmental sustainability, oil and gas sector.

Copyright @ 2019: This is an open-access article distributed under the terms of the Creative Commons Attribution license which permits unrestricted use, distribution, and reproduction in any medium for non-commercial use (NonCommercial, or CC-BY-NC) provided the original author and source are credited.

\section{Jel classification: $\mathbf{H}_{8}$}

\section{INTRODUCTION}

The environment not only accommodates the economy, it also provides the basic natural resources as inputs into productive and consumptive activities. In addition, the environment also serves as a sink for residuals generated through its assimilative capacity [1]. Since the world's awareness of the impact of anthropogenic pollutants on the environment became sharpened following the various conferences on climate change, global warming and global pollution; governments are increasingly sensitive to environmental issues. Thus, there is the existence of tripartite global environmental objectives which include environmental quality, sustainable development and biodiversity. These objectives have become the bedrock of environmental policies in the global arena. In economic literature, there are studies on the interaction between the environment and the economy for instance $[2,3]$. Several options are available for achieving environmental objectives. Economic instrument constitute a major approach used in achieving global environmental objectives.

According to Yasamis [4], the nature of environmental management thinking has witnessed a major transformation since 1990. The considerable cost advantage of enforcing environmental rules and regulations through economic instruments over command-and-control tools options has opened a new horizon for environmental policy designers. In Nigeria, there exists a plethora of acts and other legislations to combat environmental degradation in the oil and gas sector but the sector is bedeviled with unabated pollution especially gas flaring. In this vein, Ukala [5] opined that the stoppage of gas flaring in Nigeria has not been successful because of failure to enforce gasflaring legislations. Against this background, the main objective of this paper is to examine and assess the use of economic instruments for environmental protection and sustainability in the Nigerian oil and gas sector. In order to realize this objective, the paper intends to provide answers to two prong interrelated questions: What are the adequacies of economic instruments in use within the context of legal, institutional political and socio-cultural environment in the Nigerian oil and gas sector? What are the evidences showing the success and failure of the use of economic instruments in the Nigerian oil and gas sector? Following this introductory section, section 2 provides conceptual framework and theoretical underpinning of the paper. Section 3 presents the literature review while section 4 examines the lessons of experience from Malaysia in the use of 
economic instruments. Section 5 provides conclusion and policy recommendations of the paper.

\section{CONCEPTUAL CLARIFICATIONS THEORETICAL UNDERPINNING}

AND

In this section, we shall attempt to briefly but lucidly clarify the following related concepts; command-and-control approach, economic instruments and environmental sustainability. Command-andcontrol approach to environmental management is all about defining environmental standards in law by specifying them as ambient standards, technology based standards and performance-based standards. In this vein [6], opined that in shaping the early environmental policies of the 1970s, policy makers instituted standardbased systems in keeping with prevailing legal traditions of dealing with activities deemed excessive by society. By ambient standard, we mean a standard that designates the quality of the environment to be achieved, typically expressed as a maximum allowable pollutant concentration. Technology-based standard is a standard that designates the equipment or method to be used in achieving some abatement level. Performancebased standard is a standard that specifies a pollution limit to be achieved but does not stipulate technology. Early command-and-control regulations were often based on solutions with little thought given to how pollution could be reduced through systemic changes to the core production process or even in product design. Command-and-control regulations give the manufacturer little incentive to pursue such changes. Austin [7] argued that while command-and-control regulations were successful in securing the first tranche of emissions, reductions from previously unregulated industries, more than two decades after their introduction they are now viewed as increasingly burdensome. On the part of industrial stakeholders, they bemoan the financial costs such regulations impose on them and the intrusiveness of a process which often dictates their technology choice. The regulators bear the burden of keeping abreast of technological developments in many industries. Again, the process of ratcheting standards up over time often brings the two groups into antagonistic debate about the costs and suitability of alternative technologies upon which to base the best standard.

Economic instruments are incentive based policies that encourages conservation practices or pollution reduction strategies. Policy instruments are termed economic instruments (EIs) for environmental management to convey the message that their effect is to influence decision-making behavior in such a way that alternatives are chosen that lead to an environmentally more desirable situation than in their absence. They are "economic" in that they affect the estimates of the costs and benefits of alternative actions or choices open to economic agents. The economic instruments that governments have used globally to influence behavior have traditionally been fiscal instruments (taxes, subsidies, fees and charges). To this end, governments have direct control over the rate of tax, subsidy or charge as deciding how to spend any revenue raised. Available data from the Organization for Economic Co-operation and Development (OECD) sources revealed that member nations uses approximately 375 different environmental taxes as well as some 250 environmentally based fees and charges. Callan and Thomas [8] surmised that although the market approach continues to be a secondary form of control, its use in national policy prescriptions appeals to its importance as part of the range of available solutions to environmental problems. The table below depicts the categories of market-based instruments. 


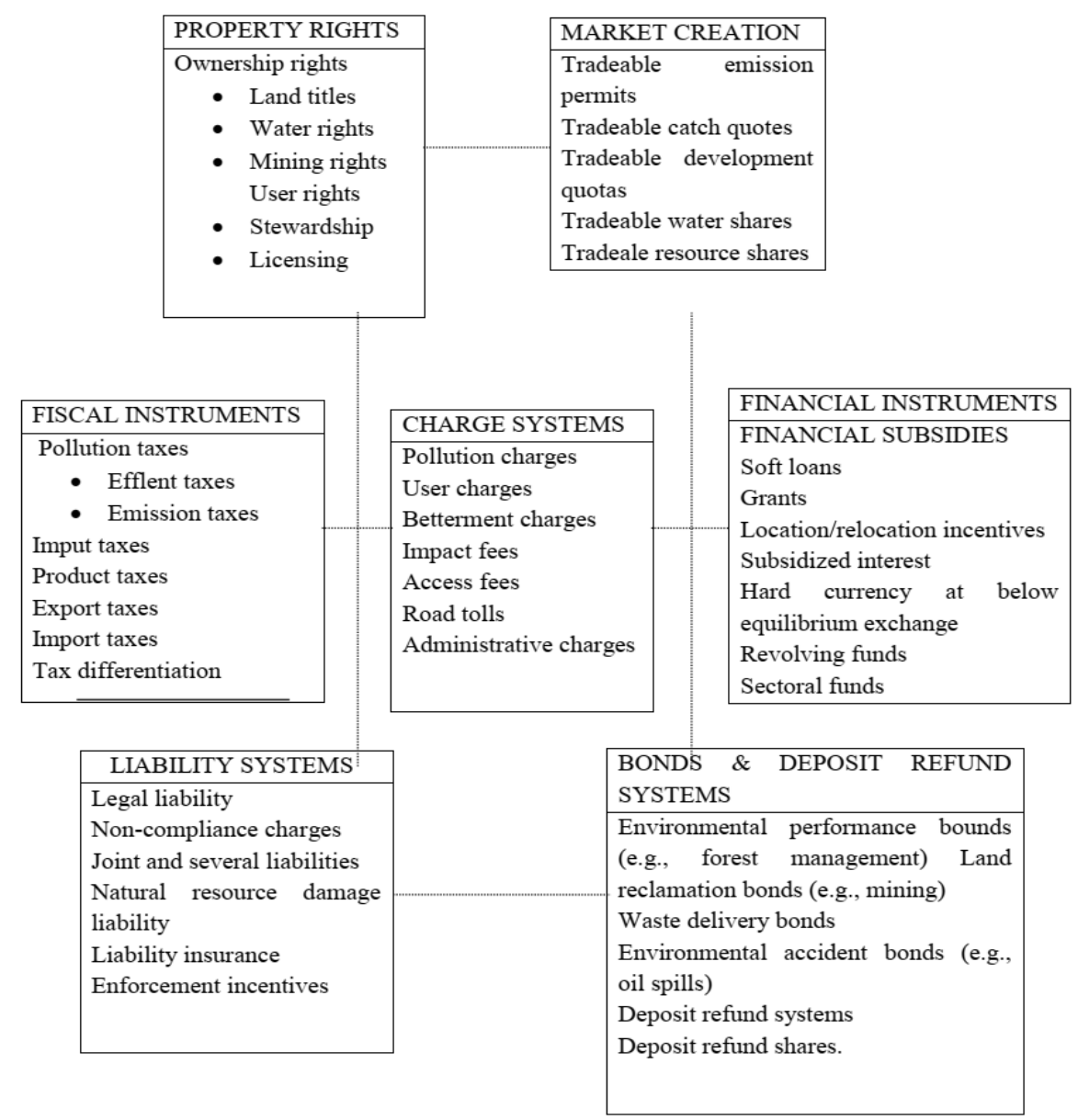

Fig-1: Economic instruments for Environmental Protection and Natural Resource Management

Source: Panatoyou, T [9] Economic instruments for environmental management and sustainability

Environmental sustainability is a cardinal objective of environmental management. It takes care of the intergenerational equity issue that requires each generation to leave a constant stock of ecological capital for the next [1]. By virtue of the fact that the environment accommodates the economy, increase in economic growth has long term environmental implications, as suggested by the materials balance model. Achieving an appropriate balance between economic growth and the preservation of natural resources is the essence of environmental sustainability. This calls for managing the earth's resources to ensure their long-term quality and abundance. By extension, this is a pointer to the fact that the circular flow of economic activity cannot be properly understood without recognizing how it fits into larger scheme of the natural environment. The global attention focused on environmental sustainability is reflected in the Rio Declaration, Johanesburg Submit, Kyotol Protocol as well as Copenhagen Submit.

In economic literature, there exist a number of theories underpinning the use of economic instruments. We shall examine the relevant ones that are suitable for this paper. In his seminal work on the tragedy of the commons [10] alarmed resource users on the tragic outcome of the present pattern of utilizing scarce and common resources. The alarm stemmed from the fact that free and unlimited nature of common resources eventually lead to the rapid deterioration of the resources because of profit maximization. All producers are profit maximizers and as such will always want to use free inputs to minimize cost. Thus, we are confronted with a situation of rapid deterioration of the scarce resources, more pollution and loss of biodiversity. This hampers the achievement of intergenerational equity and therefore constitutes a suboptinal solution [4]. An economic way of moving from this sub-optimal state is to put a price tag (mainly in the form of tax or charge) on them. The implication of such price tag will result in the property ownership structure. The concept of common property (owned by all) will transform itself into public property (owned by the public). Thus creating a semi-common goods [11].

Another way of looking at the use of economic instruments theoretically is to view it from the lens of negative externalities. Environmental degradation such as pollution can be tackled from the point of viewing it as a negative externality. 


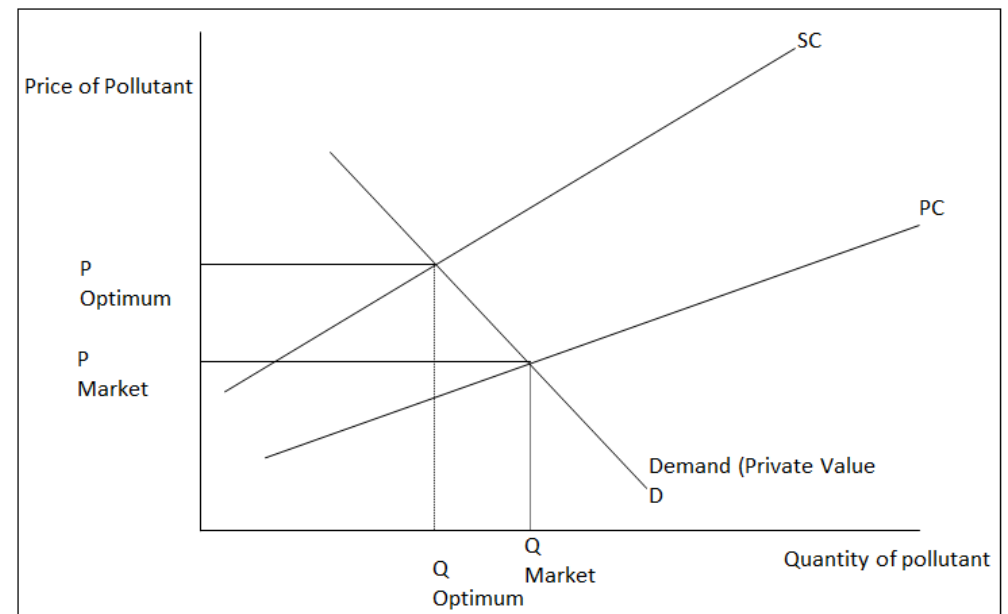

Fig-2: Pollution and social optimum

Source: Mankiw, Kneebone, Mckenzie and Rowe [12] Principles of Economics

Assuming a producer emits pollution and this emission affects the health of the inhaler of the pollutants. This constitutes negative externality. The question is how does this externality affect the efficiency of the market outcome? The cost to the society $=$ private $\cos t+$ cost to the bystanders. The difference between the cost curves reflect the cost of the pollutant emitted. Note that the equilibrium quantity is larger than the socially optimal quantity as shown in the figure above. The reason for this inefficiency is that market equilibrium reflects only the private costs of production.

According to Mankiw et al., [12] an externality arises when a person engages in an activity that influences the well-being of a bystander and yet neither pays nor receives any compensation for that effect. If the impact on the bystander is adverse, it is called negative externality but if it beneficial it is called positive externality. Negative externality can be corrected by economic instruments through Pigovian taxes by internalizing the externalities [13]. The tax/charge paying company will reflect the cost of the tax to the product thus increasing the unit price of the good. Depending on the price elasticity of the good the demand will go down thus forcing down the producer to produce less which will lead to a lesser amount of negative externality. This will eventually diminish the pressure on the environment, scarce resources and biodiversity.

The theory of environmental justice is concerned about intergenerational equity $[14,15]$ over the use of scarce resources. This is premised on the fact that scarce resources are borrowed from future generations. Pearse [16] argued that in order to make rational decisions about scarce resources, societies must be knowledgeable about their present and future values through cost and benefit as well as cost effectiveness. These analyses should be performed to better understand the real value of environmental resources.
Talking a composite view of these theories reviewed thus far, we can safely couch the theoretical foundation of this paper on the theories of the tragedy of commons, externalities and environmental justice. We premised our position on the fact that environmental problems are perceived as market failure.

\section{LITERATURE REVIEW THE ANALYTICS OF ECONOMIC INSTRUMENTS}

The aim of economic instruments is to bridge the gap between private and social costs by internalizing all external costs (both depletion and pollution costs) to their sources: the producers and consumers of the resource depleting and pollution commodities. Economic instruments aim to institute full cost pricing by costing and charging full scarcity cost for resource depletion and full damage cost for environmental degradation (See Figure-3 below). Full cost pricing is given by the formula:

$$
\mathrm{P}=\mathrm{MPC}+\mathrm{MUC}+\mathrm{MEC}
$$

Where,

$$
\begin{aligned}
& \mathrm{P}=\text { Pprice } \\
& \text { MPC = Marginal (or incremental) production } \\
& \text { cost } \\
& \text { MUC = Marginal user (or depletion) cost. } \\
& \text { MEC = Marginal environmental (or damage) } \\
& \text { cost. }
\end{aligned}
$$

Policy failures such as subsidies, reduce marginal production costs (the cost of capital, labor, energy, and materials) below the social opportunity costs, (that is, the true cost of these factors of production to society), encouraging inefficient and excessive use of subsidized inputs. Institutional failures such as open access and insecure tenure, reduce the user's benefits from the conservation of depletable resources and remove the marginal user (or depletion) cost from the decision-makers' calculus. The cost of depletion to the user is effectively set equal to zero even though the cost of depletion to society is high and 
rising. As a result the resource is undervalued, and used excessively and inefficiently.

Resource-based goods and services are thereby underpriced and over-consumed. Market failures such as environmental externalities (and public goods), leave important social costs (and benefits) outside the producer' and consumers decision calculus. The lack of market prices for environmental services effectively sets the marginal environmental cost (that is, the cost to society from the diminution of these services) equal to zero from the individual producer's or consumer's perspective. This becomes one more source of underpricing of environmentally damaging commodities and overpricing of environmentally friendly commodities. The latter is not only relatively more costly but also absolutely more costly because of the loss of resources and scale economies to highly polluting commodities.

Figure-1 Unaccounted social costs $\left(\mathrm{S}+\mathrm{MUC}_{0}+\right.$ $\left.\mathrm{MEC}_{0}\right)$, underpricing and overproduction $\left(\mathrm{P}_{0}, \mathrm{Q}_{0}\right)$ vs. internalization of external costs, full cost pricing and optimal production $(\mathrm{P}, \mathrm{Q})$; the role of economic instruments in internalizing external costs $\left(\mathrm{MUC}^{*}+\right.$ $\mathrm{MEC}^{*}$ )

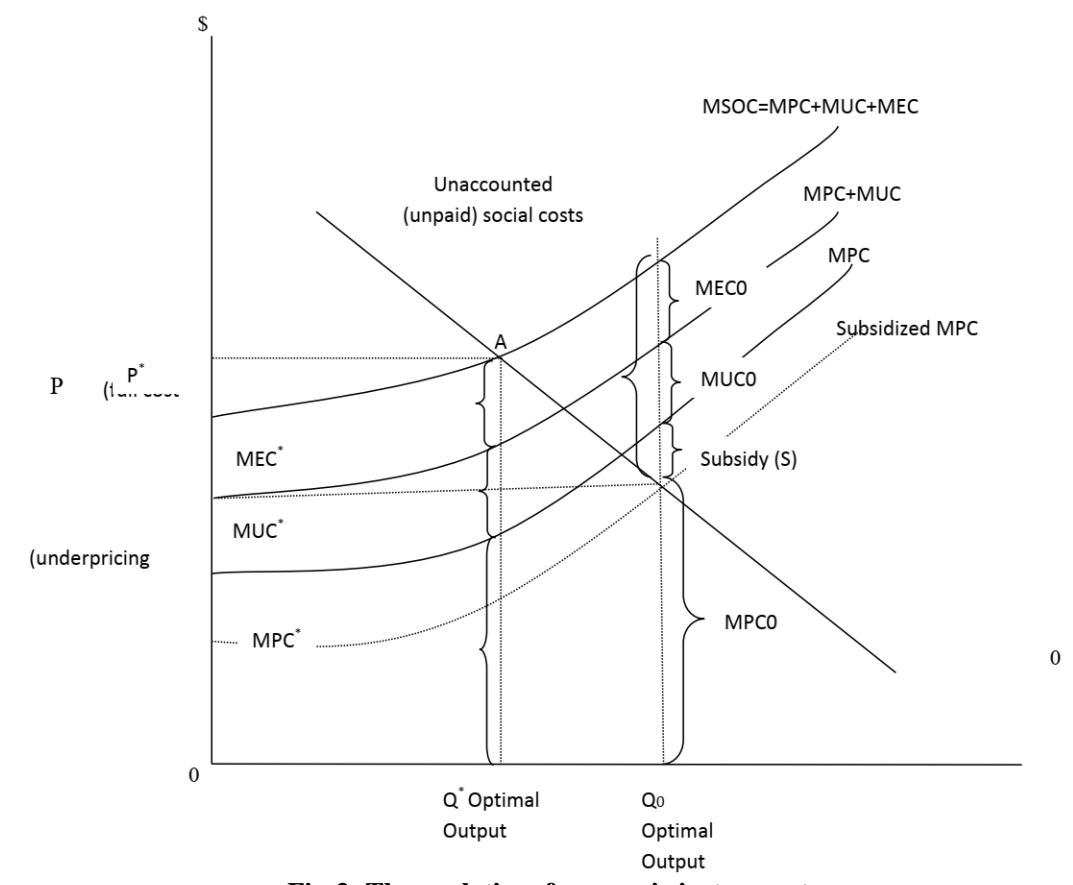

Fig-3: The analytics of economic instruments

Source: Panatoyou, T [9] Economic instruments for environmental management and sustainability

At A: $\mathrm{P}=\mathrm{MSOC}=\mathrm{MPC}+\mathrm{MUC}+\mathrm{MEC}$ where $\mathrm{P}=$ optimal price, $\mathrm{MSOC}=$ marginal social opportunity cost, MPC = marginal production cost; $\mathrm{MUC}=$ marginal user (or depletion) cost; $\mathrm{MEC}=$ marginal environmental (damage) cost.

$\mathrm{Q}=$ optimal output; resources freed by the reduction of the polluting output from $\mathrm{Q}^{0}$ down to $\mathrm{Q}^{*}$ move to other products with lower social costs (e.g., resources saving and environment-friendly).

MPC $^{*}$ internalized by removal of distortionary subsidies.

MUC ${ }^{*}$ internalized through secure property rights (assuming no discrepancy between private and social discount rates; if such discrepancy exists output taxes or tradeable production quotas can be used for further correction).

MEC ${ }^{*}$ internalized through taxes, charges, tradeable permits or other economic instruments (optimal tax $=$ optimal price of permit $=\mathrm{MEC}^{*}$ ).
ECONOMIC HISTORY AND INSTITUTIONAL
BACKGROUNDS TO THE USE OF POLICY
INSTRUMENTS IN THE NIGERIAN OIL AND
GAS SECTOR
$\quad$ The work of Elenwo and Akankali [17] traced

The work of Elenwo and Akankali [17] traced
elopment and evolution of environmental laws the development and evolution of environmental laws and regulatory framework to the early years of
independence and divided it into three major generations. The work obviously did not take into cognizance the laws in operation in the colonial period. That would be the take off point for this section. Few companies that operated in Nigeria in the preindependence era did so under the Mineral Ordinance Act 1914. In 1934, the Petroleum (Production) Act became operationalized. The Mineral Ordinance Act came into being in 1956. Following the discovery of crude oil in commercial quantities and the need to regulate transportation by pipelines, Petroleum Profit Tax Ordinance was enacted in 1959 Adelegan [18]. Vigorous regulatory activities were pursued immediately after independence in 1960. The Mineral Oil (Amendment) Act 1962 abrogated the exclusive 
rights of British registered companies to the industry by creating avenues for non-British companies. The Mineral and Oil (Safety) Regulations 1963 stipulated the first set of statutory requirements for standard practices in oil exploration activities.

The second generation of environmental laws and regulatory framework covers the period from the time the Mineral Oils (Safety) Regulation Act was enacted in 1963 to the period when the Federal Environment Protection Agency Decree 58 was enacted in 1988. This era was principally characterized by neartotal lack of public awareness concerns about environmental issues especially protection. Environmental degradation, biodiversity, sustainable environmental development, pollution abatement were not part of public discourse. Too, there was no clear cut national policy on environmental protection and by extension there was no agency entrusted with the mandate of environmental protection and development. It is pertinent to note that the Petroleum Act 1969 was a Landmark law that governs the oil and gas industry. In order to effectively evaluate and monitor the discharges into the environment, the petroleum industry is divided into six stages of operation [17]. These are explorations, production, terminal operations, hydrocarbon processing, oil transportation and marketing activities.

The third generation emanated from the dynamic nature of environmental processes. It also coincided with more global focus on environmental issues. It was during this period that the Rio Summit took place. FEPA [19] sources revealed that the Nigerian National Environmental Policies derived from the principles of global environmental practices. This requires that a number of complimentary policies and strategies are put in place which should guarantee that environmental concerns are integrated into major economic decision making process; environmental remediation costs are built into major development projects; economic instruments are employed in the management of natural resources; environmentally friendly technologies are applied; and environmental impact assessment is mandatorily carried out before any major development project is embarked upon.

The fourth or the emerging generation started with the enactment of the Local Content Act (LCA) of 2010. This is expected to evolve and mature with full implementation of LCA and Petroleum Industry Bill. The enactment of LCA seeks to regulate support services in the oil and gas sector. It is noteworthy that environmental service in the oil and gas industry is one of the support services in the aforetasted statement above. In this emerging era, the approach adopted in solving environmental problems in the National Policy on Environment is premised on an integrated, holistic and systemic view of environmental issues. Policies emanating from the LCA and PIB Act have led to the development of certain key environmental instruments and institutional organs for the general Nigerian environment and for the oil and gas in particular. 1t is remarkable to note that the Environmental Impact Assessment (EIA). Decree No. 86 of 1992 is the most outstanding of these instruments not only for the oil and gas sector but for all other industries in the country. The Department of Petroleum Resources (DPR) was the main institutional agency right from the outset of the oil and gas sector that was saddled with responsibility of formulating and implementing environmental policies within the life span of the second generation environmental policies. The DPR is still alive to her statutory role of ensuring operators' compliance to environmental guidelines and standards.

The Federal Environmental Agency was founded in 1988. Though now defunct and was subsumed into the Federal Ministry of Environment (FME) that was created in 1999 by the Chief Olusegun Obasanjo administration. The Federal Ministry of Environment fell into bureaucratic. red tapism and bottlenecks. The fall hampered the effective and efficient delivery of the given mandate within the context of implementation and enforcement of legislations. Consequent upon this major weakness of the FME, two additional regulatory bodies emerged; the National Oil Spill Detection and Response Agency (NOSDRA) and the National Environmental Standards Regulatory and Enforcement Agency were created in 2006 and 2007 through Acts No. 15 and 12 respectively. According to Adati [20] the NOSDRA focused exclusively on regulatory functions of the oil and gas sector in respect of spill detection/response and other environmental pollution arising from oil production. The NESRA focused on ensuring standards and enforcement of relevant environmental laws in all facets of Nigeria socio-economic life. It is pertinent that the creation of these agencies was a lofty idea but efficient mandate delivery has been scuttled by poor staffing and underfunding. Other institutional arrangements included: the Nigeria Maritime Administration and Safety Academy (NIMASA) and the Ecological Fund Office. At sub-national level, we have state environmental protection agencies. These agencies drive environmental policies for their respective states. The main challenge has been the incessant incidence of overlapping roles with FEPA and conflict of interest. Other important components of the institutional arrangements included Non-Governmental Organizations (NGOs) and professional bodies. Elenwo and Akankali [17] argued that though this category of institution is contributing meaningfully to green Nigeria, their roles are barely recognized. The Environmental Managers Association of Nigeria (EMAN) has the potentials as the council to regulate environmental practice in Nigeria. The figure below illustrates the inter connectedness of the institutional arrangement for environmental management in Nigeria. 


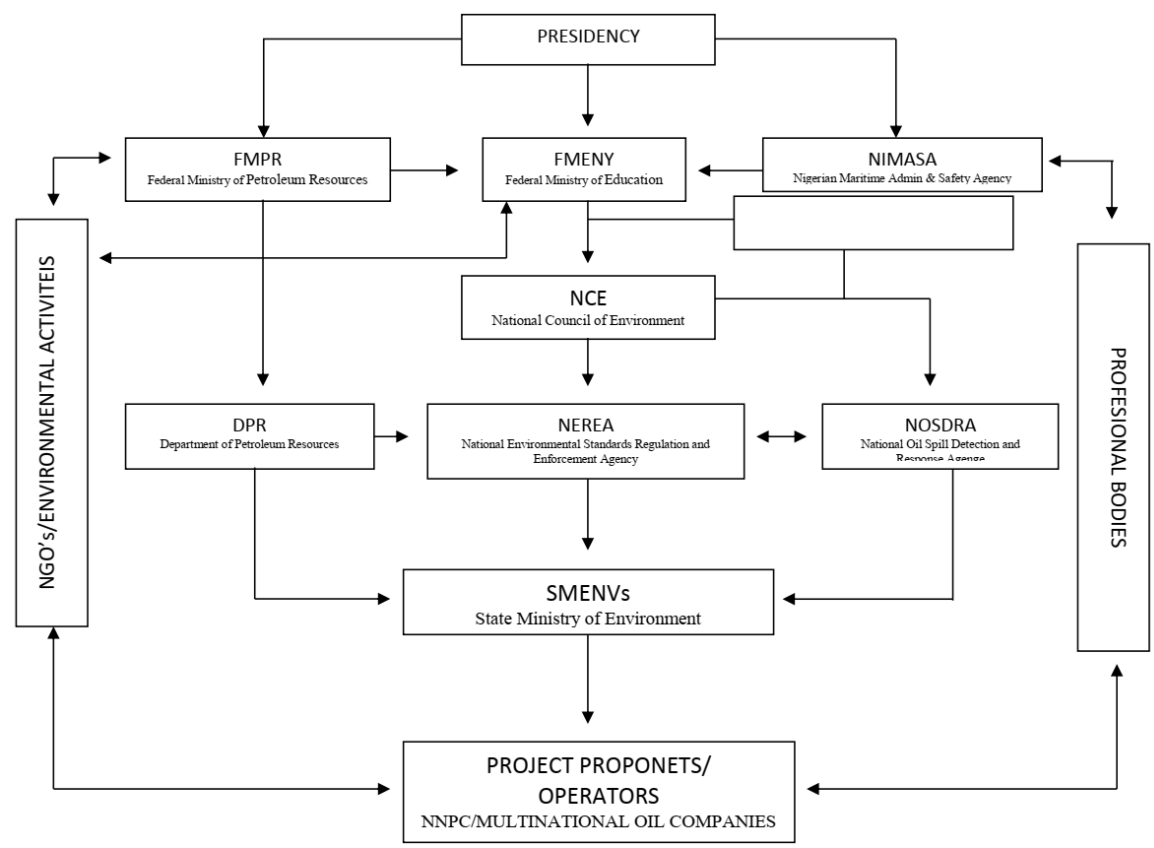

Fig-4: Institutional arrangement for environmental management in Nigeria

Source: Elenwo, E. I and J. A Akankali [17] Environmental policies and strategies in Nigerian oil and gas industry; Gains challenges and prospects.

\section{THE BENEFITS AND CHALLENGES OF USING ECONOMIC INSTRUMENTS FOR ENVIRONMENTAL MANAGEMENT}

The main focus of using economic instruments is to influence the behavior of economic agents to the generation of anthropogenic pollutants in the environment. This is done by sending indirect signals to indicate the preferred mode of behavior for both consumers and producers. Economists have championed economic instruments mainly on the grounds of three key advantages they hold over traditional forms of regulation [7].

First, economic instruments promote static efficiency (or cheaper at present). This is borne out of the fact that operators in the oil and gas sector take different actions and has different levels of emissions, some operators find it relatively cheap to undertake reductions while others find it more expensive. The overall cost of reduction is less expensive than if all firms were required to meet a uniform standard. In reality, oil firms are far from uniform. They tend to operate different technologies, use slightly different processes, and will vary with respect to size, scale, age and overall efficiency. Economic instruments can achieve a given level of environmental protection for lowest overall cost by creating a framework that allows for differential response by companies depending on their abilities to make reductions. Meanwhile, target-or performance based command and control regulation is less efficient because it ignores the fact that some firms can make reductions more cheaply than others. In order to control the overall level of pollution, the regulator simply adjusts the level of charge (or the quantity of permits).
Secondly, economic instruments enhance dynamic efficiency (or cheaper in the future). An economic instrument creates a permanent incentive for environmental improvement thus accelerates the development of new and cheaper pollution reducing technologies. Under a command-and-control regime, firms invest to meet the standard and then stop. In addition, the use of economic instrument allow state or federal regulatory agency to raise money. Such funds can either be used to finance environmental clean ups or replace existing taxes. Furthermore, economic instruments grant firms and individuals greater autonomy in deciding how to meet targets. Besides, economic instruments reduce information burden on regulators. UNECE [21] advanced some cogent reasons for the failure of economic instruments in Uzbekistan. The reasons are quite instruct similar to the reasons why economic instruments have not yielded the desired results. These include: lack of legislative and institutional capacity; weakness of environmental agencies; inadequate information concerning the cost and benefits of the economic instruments in use. Other challenges include low level of pollution charges, fines and penalties for exceeding limits are not sufficiently severe and more than often it is more-cost-effective for firms to pay fines rath er than invest capital in reducing the pollution problem.

Thirdly, a key benefit of economic (fiscal) instruments is that they would allow a given pollution target to be met for lower overall cost than traditional regulations - a considerable advantage given the perceived high financial traditional burdens of regulatory compliance. Economic instruments grant firms and individual greater autonomy in deciding how to meet targets. Others include creating ongoing 
incentives for firms to design new and improved abatement technologies ensuring that pollution control become even cheaper, reduce information burden on regulators and provide potential revenue sources for state and federal governments.

In addition, they provide greater flexibility in dealing with smaller and diffuse emissions sources which collectively contribute large amounts of pollution, but which until now have been largely ignored in favour of controlling the pollution from more obvious sources.

\section{SELECTION OF ECONOMIC INSTRUMENTS}

The use of economic instruments to achieve environmental sustainability is anchored on assessing and selecting the tools by asking and answering pertinent questions discussed below:

\section{Environmental Effectives}

Will the chosen instruments achieve pre-stated environmental objectives within the specified time frame? What is the acceptable level of deviation of actual outcome from set goals? Generally, the acceptable margin of error is higher for reversible environmental damage than for irreversible loss of unsubstitutable assets e.g biodiversity species loss and generation of hazardous waste.

Will the selected instruments achieve pre stated objective with the minimum possible cost to the society? Most economic instruments if rightly chosen can correct existing distortions with a negative distortion cost (i.e a correction benefit). The flip side of this is that there are economic instruments for instance, subsidies which through equivalents to environmental taxes encourage entry into the producing industry thereby increasing pollution.

\section{Flexibility and Efficiency}

Is the economic instrument in question flexible enough to adjust to changes in technology, resource scarcity and market conditions? Also, does the instrument provide incentives for developing and adopting new environmentally cleaner and economically more efficient technologies? It is remarkable to note that charges and tradable permit meet this criterion while efficient standards or mandated technology do not.

\section{What Happens to Equity?}

Will the costs and benefits of the instrument be equitably distributed? Environmental taxes tend to be more regressive when compared to regulatory standards. Pollution control costs fall more heavily on low income groups especially with product taxes or pollution charges that affect consumptions (food, clothes and shelter) on which the poor expends a higher proportion of their income.
Ease of Introduction, Monitoring and Enforcement

The relevant question here is; how difficult or costly will introduction, monitoring and enforcement be? This is partly anchored on the administrative capacity of the country in question. It is pertinent to infuse monitoring and enforcement activity into community resource management and customary use of rights of affected community. This will ensure that monitoring and enforcement cost are decentralized and internalized into communities which enforce them using their own internal organization, kinship relationships and social norms.

\section{The Question of Acceptability}

Is the instrument clear, lucid and understandable to all stakeholders (the public, industry and regulators)? Hidden costs are embedded in command and control regulation unlike economic instrument where they are transparent. For instance, product taxes, pollution charges, user fees, environment bonds and liability system are too transparent. It become difficult to promote the use of economic instruments when it is not clear to the industry, environmental groups and the public, the costs and benefits of available options.

\section{Congruence with Existing Legislative Framework}

Is the instrument consistent with the country's legislative framework? If new legislation is necessary, how feasible is it? Does the executive arm of the government have the administrative capacity to issue required regulations and administer the instruments? The above are the pertinent questions to ask.

\section{A REVIEW OF THE MALAYSIAN EXPERIENCE}

Economic instruments are not new to developing countries neither are they foreign to nonWestern cultures. Rural traditional societies have a wealth of customary use rights, communal management systems and customs that provide incentives for efficient use and management of natural resources. These systems contain valuable lessons and vital elements for the design of effective modern systems of managing natural resources in developing countries. While the theoretical justification for the use of economic instruments is sound, its practicability differs in different federal systems based on historical antecedents and cultural milieu.

A survey of Malaysia' experience points to a situation that where the will and determination to adopt the use of economic instruments successfully is strong, the gains are evident. Looking into the Malaysian effluent charge system revealed that as far back as 20 years ago, the Malaysian Environmental Quality Act of 1974 included provisions for using economic incentives and disincentives in the form of effluent charges in support rather than a replacement for regulatory controls can discharges. The discharge fees provided by the act were combined with discharge standards that 
developed into an incentive- supported regulatory regime controlling effluent charges from palm oil mills. The foregoing was done in 1977 and the first discharge fee was collected in 1978. Over time the standards became more stringent and the discharge fees became larger. There was a steady increase in palm oil mills and a s steady growth in palm oil production, the total biochemical oxygen demand (BOD) had released in public water bodies dropped steadily from 222 tons per day in 1978 to 58 tons in 1980, 19 tons in 1992 and 5 tons in 1984. This was a remarkable achievement in palm oil effluent charge management system. It is note worthy that charging high effluent charges as well as granting incentives by way of fees for research accelerated the pace of research to solve this problem. Vincent (1993) examined in detail the economic efficiency of the Malaysian effluent standard and charge system, the research used an economic model of cost-maximizing abatement and disposal behavior by palm oil mills. The result revealed that despite its effectiveness in controlling palm oil production, the Malaysian mixed regulation-incentive system was not economically efficient in spite of its weaknesses, the Malaysian model holds valuable lessons for developing countries that are contemplating the introduction of economic instruments in support of their environmental regulations.

\section{ECONOMIC INSRUMENTS FOR ABATING GAS FLARING IN NIGERIA}

Prior to the recent gazette, the enforcement of charges in the Nigerian oil and industry has been sloppy. The government is now taking stricter regulation of oil extraction activities in the Niger Delta. A recent gazette spelt out new stringent regulatory measures that will apply in oil production, especially as it concerns gas flaring. Now there is imposition of higher fines, which many believe is long over-due, but will discourage the act and its deleterious effects on humans and the environment. From the previous fine of N10 for every 1,000 standard cubic feet of gas flared, which many saw as a slap on the wrist. A stiffer Penalty of \$2 per every 1000 scf of gas flared has been imposed. At the current exchange rate of N306 to a dollar the fine now stands at over N600 per 1,000 scf of gas. In the gazette Gas Flare (Prevention of Waste Pollution) Regulatin 2018 indicate that declaration of false data would attract a fine of N50,000 or six months jail term or both. Beside this, a fine of $\$ 2.50$ will also be paid for failure to produce adequate flare data; failure to provide access to flares site and failure to sign a connection agreement.

This is a new era of getting oil companies to behave more responsibly, transparently and in accordance with international best practices. The $\$ 2.00$ fine is target at companies producing more than 10,000 barrels per day, those producing less are not left off the hook, they are required to part with $\$ 0.5$ per 1,000 sale of gas flared in the process of oil production.
Gas flaring has persisted in the country despite many timelines set by the government to end it. Efforts to end flaring date back to the enactment of the Associated Gas Reinjection Act of 1979, which set a deadline of 1984 for gas flaring. Unfortunately the companies have maintained that it is uneconomical to embark on gas reinjection as an alternative to flaring and since the penalty was a paltry N10 per $1000 \mathrm{scf}$ of gas fared, it was convenient for them to pay up. No measures can be considered too tough to stop gas flaring.

The global financial Agency which is working with oil companies and countries to end the menace describe the practice a waste of valuable energy resource that could be used to advance sustainable development of producing countries. The World Energy Council is disappointed that Nigeria is not maximizing the opportunity provided by gas for economic diversification. What should be a cheap source of clean energy is being blatantly wasted.

Although believed to have keyed into the World Banks Zero Routine flaming by 2030 initiative, Nigeria has also set a new personal deadline of 2019 for ending gas flaring. The Minister of State for Petroleum Resources Ibe Kachikwu said that companies that could not stop gas flaring 2019 should stop production.

\section{CONCLUSION AND RECOMMENDATIONS}

This paper examined the use of economic instruments for environmental sustainability in the Nigerian oil and gas sector. The paper focused on gas flaring as a major avenue of environmental degradation in Nigeria. Over the years, Nigeria has relied heavily on command - and - control approach to environmental management in the oil and gas sector. The use of economic instruments become imperative owing to the shortcoming of the command - and - control approach and the benefits of using economic instruments.

The use of economic instruments in the Nigerian oil and gas sector is not a new approach but its use has been limited as a result of shortage of will and determination on the part of the government. The good news is that a new gazette of stiffer penalties has been enacted to drive the use of economic instruments in the oil and gas sector. It is the contention of this paper that the contents of the gazette be vigorously pursued to logical conclusion.

\section{RECOMMENDATIONS}

The following are the recommendations emanating from the study;

- The use of command - and - control approach should not be jettisoned but rather be strengthened by the use of economic instruments.

- The government should muster necessary and sufficient will and determination to actualize the gains of using of economic actualize the gains of 
using of economic instruments in the Nigerian oil and gas sector.

- Strict enforcement of the charges as contained in the Gas Flare (Prevention of Waste) Regulation 2018.

\section{REFERENCES}

1. Obadan, M. I., \& Egbon, P. C. (1995). The environment and policy instruments. Ncema policy Analysis Series, 1(1).

2. Sambo, A. S. (2010). Energy and environmental interactions for sustainable economic growth of Nigeria. Proceedings of 2010 annual conference on energy environment and economic growth. Nigerian Association for Energy Economics.

3. Omorogbe, Y. (2014). Energy access and economic development: Policies, institutional frameworks and strategic options. A keynote address in the proceedings of 2014 NAEE annual conference on energy access and economic development. Nigeria Association for Energy Economics.

4. Yasamis, F. D. (2011). Economic instruments for environmental management. International Academy of Ecology and Environmental Sciences, 1(2): 97-111.

5. Ukala, S. C. (2008). Intellectuals Should Show the Way Forward in Film Production. Film Nigeria: An International Journal of the Nigerian Film, 1(1), 12.

6. Spence, A. M., \& Weizman, M. L. (1994). Regulatory strategies for pollution control in economics of the environment. Selected readings, edited by Robert Dorfman and Nancy Dorfman, ww. Nortion New York.

7. Austin, D. (1999). Economic instruments for pollution control and prevention- A brief overview. World Resources Institute, Policy Report.

8. Callan, S. J., \& Thomas, J. M. (2013). Environmental economics and management: Theory, policy, and applications. Cengage Learning.
9. Llanto, G. M., \& Magno, M. T. (1994). The impact of agrarian reform on credit markets in the aquaculture sector (No. 1994-09). PIDS Discussion Paper Series.

10. Hardin, G. (1965). The tragedy of the commons. Science, 162(5), 1243-1248.

11. Depoorter, B. (2005). Never two without three; Commona, anti commons, and semicommons. Law School University of Miami. http://sbrn.com/abstract=1162189

12. Mankiw, N. G., Kneebone, R. D., Mckenzie, K. J., \& Rowe, N. (2006). Principles of Economics. Ontario, Thomson Canada Ltd.

13. Pigou, C. (1932). The economics of welfare Macmillan, New York.

14. Solow, M. R. (1974). Intergenerational equity and exhaustible resources. The Review of Economic studies, 41; 29-45.

15. Holberg, N., \& Baumgartner, S. (2011). Irreversibility, ignorance and intergenerational equity-efficiency trade off. http://papers.ssrncom/so13/apapers.cfm?abstractid $=1764443$

16. Pearce, D., Atkinson, G., \& Mourato, S. (2006). Cost-benefit analysis and the environment: Recent developments OECD, Paris, France.

17. Elenwo, E. I., \& Akankali, J. A. (2014). Environmental policies and strategies in Nigerian oil and gas industry; Gains challenges and prospects. Natural resources, 5, 884-896.

18. Adelegan, A. E. (2017). Oil and gas law reforms and its implications for economic development in Nigeria. International Journal of Development and Economic Sustainability, 5(3).

19. Federal Environmental Protection Agency (FEPA). (1998). Draft revised national policy on the environment under the auspices of UNDP supported environment and natural resources management program. For Nigeria.

20. Adati, A. K. (2012). Oil exploration and spillage in the Niger Delta of Nigeria. Civil and Environmental Research, 2(38).

21. UNECE. (1998). Role of economic instruments in integrating environmental policy with setoral policies ECE/CEP/60. 